\title{
Essay
}

\section{Brown and the Afrocentric Curriculum}

\author{
Sonia R. Jarvisł
}

\section{INTRODUCTION}

When the Supreme Court rendered its landmark decision in Brown v. Board of Education ${ }^{1}$ over three decades ago, it expected that public schools in America would eventually cease to be segregated on the basis of race. Yet in spite of thirty-eight years of desegregation efforts, the goal of equal educational opportunity remains elusive. Meaningful progress in the integration of public schools for black children has not happened since the early 1970's, and in the twenty-five largest inner-city school districts there are actually more racially segregated schools today than existed in $1954 .^{2}$ The issue of race in public education continues to generate intense debate-whether the discussion centers on longstanding desegregation orders in school busing cases, the inclusion of minority perspectives in curricula (from elementary schools to universities), ${ }^{3}$ or the use of scholarships based on race. Moreover, the Supreme Court has

† Executive Director, National Coalition on Black Voter Participation; B.A., Stanford University, 1976; J.D., Yale Law School, 1980.

1. 347 U.S. 483 (1954).

2. Gary Orfield \& Franklin Monfort, Status of School Desegregation: The Next Generation 11 (Jan. 8, 1992) (prepublication copy of report to the National School Boards Association, on file with author). See COMRITTEE ON POLICY FOR RACIAL JUSTICE, VISIONS OF A BETTER WAY: A BLACK APPRAISAL OF PUBLIC SCHOOLING 13-22 (1989); JONATHAN KOZOL, SAVAGE INEQUALITIES 3 (1991); SHADES OF BROWN: NEW PERSPECTIVES ON SCHOOL DESEGREGATION (Derrick Bell ed., 1980); Robert Carter, Reexamining Brown Twenty-Five Years Later: Looking Backward into The Future, 14 HARV. C.R.-C.L. L. REV. 615, 620 (1979).

3. Jerry Adler et al, African Dreams, NEwsweEk, Sept. 23, 1991, at 42-45; Michel Marriott, Afrocentrism: Balancing or Skewing History?, N.Y. TnES, Aug. 11, 1991, § 1, at 1; Calvin Sims, World Views: Separatists and Pluralists Lay Claim to Multicultural Mantle, N.Y. TIMES, Nov. 4, 1990, § 4, at A23. 
demonstrated increasing antipathy toward race-conscious remedies designed to overcome discrimination in education, employment, and housing. Since Milliken v. Bradley, ${ }^{4}$ the Court has retreated from an affirmative role in redressing the effects of decades of segregated education, a retrenchment most recently reflected in Board of Education v. Dowell, ${ }^{5}$ which concerned a desegregation order in a case originally filed in 1961.

Recent developments in education have challenged Brown's central premise that separate schools are inherently unequal. ${ }^{6}$ In reaching its conclusion that the separate but equal doctrine has no place in public education, Brown relied heavily on sociological data that suggested that segregated public schools stigmatized African-American children by generating "a feeling of inferiority as to their status in the community that may affect their hearts and minds in a way unlikely ever to be undone." The Court's reliance on sociological data continues to be controversial. Since Brown, numerous studies have shown that while some Black children benefit from attending school with white children, others lose confidence and actually perform more poorly because of discriminatory tracking programs and teachers' negative attitudes toward black children. ${ }^{8}$

Given the persistence of all-Black public schools and doubts about Brown's sociological premises, some educators are searching for viable solutions and have begun to promote the adoption of an Afrocentric curriculum. ${ }^{9}$ Afrocentric

4. 418 U.S. 717 (1974).

5. 111 S. Ct. 630 (1991) (allowing desegregation decree to be lifted or modified if lower court finds that "vestiges of past discrimination had been eliminated to the extent practicable"). Good faith compliance with a decree could terminate a desegregation decree even if existing residential segregation would cause resegregation of that school district.

6. The Supreme Court concluded "that in the field of public education the doctrine of "separate but equal' has no place. Separate educational facilities are inherently unequal" and therefore violative of "equal protection of the laws guaranteed by the Fourteenth Amendment." Brown, 347 U.S. at 495 . Nevertheless, as of 1980, two-thirds of Black children attended public schools in which over half of the students were minorities. COMMTTEE ON THE STATUS OF BLACK AMERICANS, NATIONAL RESEARCH COUNCI, A COMMON DESTINY: BLACKS AND AMERICAN SOCIETY 76 (Gerald Jaynes \& Robin Williams, Jr. eds., 1989) [hereinafter COMMON DESTINY]. Since Brown overturned the separate but equal standard, historically Black colleges have been criticized for remaining racially identifiable, yet these colleges have continued to produce larger numbers of Black graduates. Derrick Bell, The Politics of Desegregation, CHANGE, Oct. 1979, at 50.

7. Brown, 347 U.S. at 494.

8. See JACQUELINE J. IRVINE, BLACK STUdENTS AND SCHOOL FAILURE: Policies, PRACTICES, AND PRESCRIPTIONS 9-12 (1990) (citing various studies on the deleterious effects of tracking on Black students' achievement and the disproportionate placement of Black students in such programs); see also Carl Grant, Desegregation, Racial Attitudes and Intergroup Contact: A Discussion of Change, PHI DELTA KAPPA, Sept. 1990, at 25, 30-31; Serge Madhere, Self-Esteem of African American Preadolescents: Theoretical and Practical Considerations, 60 J. NEGRO EDUC. 48 (1991). Even Kenneth Clark, the developer of the famous doll study used in Brown to show Black children's feeling of inferiority, has questioned the strategy of basing constitutional policy on social science research. See Kenneth B. Clark, A Personal View of the Background and Developments Since the Brown Decision, in BROWN PLUS THIRTY: PERSPECTIVES ON DESEGREgATION 18 (1986); see also Wallace Loh, In Quest of Brown's Promise: Social Values in School Desegregation, 58 WASH. L. REV. 129, 133 n.29 (1982).

9. Molefi K. Asante, The Afrocentric Idea in Education, 60 J. NEGRo Educ. 170-80 (1991); Madhere, supra note 8, at 47-48; Gerald Pine \& Asa Hilliard, III, Rx for Racism: Imperatives for American Schools, PHI DELTA KAPPAN, Apr. 1990, at 593, 595-98. For a description of what an Afrocentric curriculum entails, see infra text accompanying notes 57-59. 
curriculum advocates accept Brown's premise that stigma is the greatest obstacle to Black students' educational opportunities. However, they argue that even if Brown was correct to order integration, the persistence of segregation and the uneven effects of integration make an alternative curriculum appropriate for removing the stigmas Black children still face in schools that have resegregated (or never were desegregated). Advocates such as Professor Tsehloane Keto and Professor Molefi Kete Asante assert that Black children will no longer feel a need to reject their Blackness as a "badge of inferiority" if given the opportunity to study from an Afrocentric perspective. The societal contributions of their ancestors and their own experiences would not be marginalized or devalued. ${ }^{10}$ In practical terms, such a perspective would improve Black children's selfesteem and ability to function in society at large. ${ }^{11}$

Political debate continues to rage over issues such as affirmative action in employment and higher education. Legal disputes have arisen over the use of public funds to establish all-Black, all-male academies and to provide tuition vouchers for public school students to attend private schools. Such controversies suggest that a school board's decision to adopt an Afrocentric curriculum would also encounter serious debate and possible legal challenge. ${ }^{12}$ This Essay argues that the implementation of an Afrocentric curriculum that seeks to enhance the self-esteem and academic performance of Black children is consistent with Brown. Part I focuses on the role of race in the development of public education and suggests that integration has never been fully supported as a model for achieving equality in education either before or since Brown. Part II examines the current debate over Afrocentric curricula, a debate prompted in large part by the retrenchment from Brown. The central issue is whether such programs improve the self-esteem and achievement levels of Black children-an issue that was one of the main concerns of the Supreme Court in Brown-or encourage separatism, a return to the discredited "separate but equal" doctrine.

10. TSEHLOANE KETO, THE AFRICA-CENTERED PERSPECTIVE OF HISTORY 25-28 (1989); Asante, supra note 9, at 171. The Supreme Court in its infamous decision, Plessy v. Ferguson, 163 U.S. 537, 551 (1896), coined the phrase "badge of inferiority" in announcing that it was constitutionally permissible to force Blacks to ride in separate railroad cars:

We consider the underlying fallacy of the plaintiff's argument to consist in the assumption that the enforced separation of the two races stamps the colored race with a badge of inferiority. If this. be so, it is not by reason of anything found in the act, but solely because the colored race chooses to put that construction upon it.

11. Asante, supra note 9, at 177; William E. Nelson, Jr., School Desegregation and the Black Community, 17 THEORY INTO PRACTICE 122, 125 (1978).

12. In September 1991, the Detroit School Board announced plans to open an all-male, all-Black academy to deal with the special problems of Black boys; the academy would also use an Afrocentric curriculum. The school board was enjoined from opening the academy on the basis of sex discrimination; it has subsequently agreed to admit girls. The court did not reach the issue of the Afrocentric curriculum. See Garrett v. Board of Educ., No. 91-CV-73821-DT (D. Mich. Aug. 15, 1991).

Milwaukee recently instituted a voucher program to allow lower income public school students to apply tuition tax credits to tuition fees at private schools. This plan was recently found constitutional by the Wisconsin Supreme Court. Carol Innerst, 'Shot in the Arm' for School Choice, WASH. TMMES, Mar. 5, 1992, at $\mathrm{Al}$. 
Part III argues that an Afrocentric curriculum does not repudiate the principles established in Brown if greater educational achievement and opportunity result from its adoption.

\section{THE SPIRIT OF BROWN}

\section{A. The Promise of Brown}

The historical significance of Brown's role in ending state-imposed segregation and its impact on constitutional analysis has been firmly established. ${ }^{13}$ The Brown decision is commonly understood as declaring that racially segregated public schools were impermissible under the Fourteenth Amendment and, by extension, the Fifth Amendment. By removing the imprimatur of state approval from segregation, the Court assumed that with time, Black schoolchildren would no longer be stigmatized by attending separate schools and would instead receive better educational opportunities in racially integrated school settings. The Court worried that racial isolation reinforced the feelings of inferiority Black children experienced from living in a "Jim Crow" society.

Because Brown rejected the very second-class citizenship afforded African Americans in earlier Supreme Court cases such as Dred Scott $v$. Sandford ${ }^{14}$ and Plessy v. Ferguson, ${ }^{15}$ Brown has had a profound impact on the dismantling of apartheid in America. In fact, it revitalized the Fourteenth Amendment's original purpose: to help Blacks claim their right to national citizenship. ${ }^{16}$ Not only was Brown the authority for the prohibition of segregation in a wide range of public activities, it provided the legal underpinnings for the Civil Rights Act of 1964. Brown also led to a broader interpretation of the Fourteenth Amendment in areas unrelated to race. ${ }^{17}$ It is undisputed that following Brown and the enactment of the various civil rights acts, some African Americans became assimilated into the mainstream of American life in areas such as political participation, private and public sector employment, and housing.

13. See, e.g., RICHARD KLUGER, SIMPLE JUSTICE (1975); U.S. COMM'N ON CIVL RIGHTS, TWENTY YEARS AFTER BROWN 1-29 (1975); STEVEN WASBY ET AL., DESEGREGATION FROM BROWN TO ALEXANDER 93-100 (1977); J. HARVIE WILKINSON, III, FROM BROWN TO BAKKE (1979); RAYMOND WOLTERS, THE BURDEN OF BROWN: THIRTY YEARS OF SCHOOL DESEGREGATION 3-5 (1984); see also LNO A. GRAGLIA, DISASTER BY DECREE: THE SUPREME COURT DECISIONS ON RACE AND THE SCHOOLS 256-57 (1976).

14. 60 U.S. (19 How.) 393 (1857).

15. 163 U.S. 537 (1896); see also supra note 10.

16. “Brown's broad meaning, its important meaning, is its revitalization of the national constitutional right the Thirteenth, Fourteenth, and Fifteenth Amendments created in favor of Negroes. ... Brown erased Dred Scott, used the Fourteenth Amendment to breathe life into the Thirteenth, and wrote the Declaration of Independence into the Constitution." United States v. Jefferson County Bd. of Educ., 372 F.2d 836, 87273 (5th Cir. 1966), aff'd, 380 F.2d 385 (5th Cir) (en banc), cert. denied, 389 U.S. 840 (1967).

17. See generally Jefferson County, 372 F.2d at 872; DERRICK BELL, RACE, RACISM, AND AMERICAN LAW 377-84 (2d ed. 1980); ALEXANDER BICKEL, THE SUPREME COURT AND THE IDEA OF PROGRESS 7 (1970); HUGH D. GRAHAM, THE CIVIL RIGHTS ERA: ORIGINS AND DEVELOPMENT OF NATIONAL POLICY $1960-1972$, at 367 \& n.8 (1990); WASBY ET AL., supra note 13, at 148-49. 


\section{B. Implementing Brown: The Lack of Progress}

Progress in the area of equal educational opportunity, however, has been limited. ${ }^{18}$ Desegregation of the public schools created massive resistance, "white flight" from the cities to the suburbs, and a tremendous displacement of Black teachers and administrators. ${ }^{19}$ The white community's opposition to busing became a constant factor in national and local politics, and even Black parents began to question whether the price their children were paying to desegregate previously all-white schools was too high. ${ }^{20}$ The federal court system was inundated with protracted litigation over the implementation of desegregation orders, and in many cases, federal judges became enmeshed in the daily administration of public school systems.

Clearly, the Court's recognition that state-sponsored segregation in public education violates the Equal Protection Clause of the Fourteenth Amendment has not made equal educational opportunity a reality. ${ }^{21}$ Indeed, a noted commentator on public education recently observed that the educational opportunities available to Black children in inner-city schools more closely resemble the conditions extant when Plessy was decided nearly 100 years ago than those when Brown was written. ${ }^{22}$ Even those who believed that the elimination of de jure segregated education would result in equal educational opportunity now concede that Brown's promise has not been fulfilled..$^{23}$ Brown's critics argue that by promoting integration rather than mere desegregation-namely racial balance rather than simply color-blind, nonracial admissions-Brown has wrought the resegregation of the nation's schools. ${ }^{24}$

When the Supreme Court announced in Brown $I I^{25}$ that it would implement Brown on a gradual case-by-case basis, it was attempting to provide Americans with time to adjust to the new reality required by the decision. ${ }^{26}$ Yet this approach simply encouraged massive resistance in the South to the desegregation of dual school systems. ${ }^{27}$ Some states followed the lead of

18. See, e.g., COMMON DESTINY, supra note 6, at 74-84.

19. See Robert L. Gill, Brown II v. Board of Education of Topeka: Its Human Advances and Human Tragedies, 1955-1980, 32 NEGRO EDUC. REV. 15, 39 (1981); Nelson, supra note 11, at 124. "White flight" describes the phenomenon in which large numbers of white families move from urban areas to suburban areas to avoid sending their children to recently desegregated schools.

20. Gill, supra note 19.

21. Cf. Drew Days III, School Desegregation Law in the 1980's: Why Isn't Anybody Laughing?, 95 YALE L.J. 1737, 1738 n.3 (1986).

22. KOZOL, supra note 2.

23. See Carter, supra note 2; Clark, supra note 8, at 18.

24. See GRAGLIA, supra note 13, at 256-62; THOMAS SOWELL, CIVIL RIGHTS: RHETORIC OR REALITY 65-69 (1984).

25. Brown v. Board of Educ., 349 U.S. 294 (1955) (Brown II). Brown II's famous phrase that desegregation should occur "with all deliberate speed" inspired resistance to Brown. See, e.g., Griffin v. County Sch. Bd., 377 U.S. 218, 223 (1964) (school board actually closed public schools during 1959-1963).

26. WASBY ET AL., supra note 13, at 124-29.

27. GRAHAM, supra note 17 , at 373 . 
Briggs v. Elliott ${ }^{28}$ and adopted so-called "freedom of choice" plans. In Briggs, one of the original companion cases to Brown, the court held that the Constitution does not require integration but merely forbids discrimination. Because it does not forbid segregation that occurs as a result of voluntary action, the Briggs court reasoned, people still had the "freedom to choose" their children's school. ${ }^{29}$

This tension over whether Brown required integration or just desegregation allowed freedom of choice plans and other obstructionist tactics to impede the creation of unitary nonracial school systems. In fact, the Court did not formally abandon Brown II's "all deliberate speed" statement until some fifteen years after Brown. ${ }^{30}$ An important break came when the Supreme Court disapproved freedom of choice plans in Green v. County School Board. ${ }^{31}$ The Court proclaimed that Brown's goal was a system without a "white" school or a "Negro" school, but "just schools." The Court repeated this position in Raney v. Board of Education. ${ }^{32}$ Three years later, a unanimous Court ruled that a school board properly took race into account in fixing attendance lines as part of its affirmative duty to disestablish a de jure dual system. ${ }^{33}$

Even where a system was partially segregated on a de facto rather than a de jure basis, the Court found that a school board had the burden of showing its "racially neutral" neighborhood school policy was not motivated by an intent to segregate. ${ }^{34}$ This 1973 ruling, Keyes v. School District No. 1, represented the high water mark in the Court's commitment to unitary school systems. Keyes, taken together with Swann v. Charlotte-Mecklenburg Board of Education, ${ }^{35}$ allowed courts to order busing to the extent necessary to effectively desegregate school systems even in de facto settings.

The desegregation tide began receding with the 1974 decision Milliken $v$. Bradley. ${ }^{36}$ The Supreme Court had not reversed a school desegregation order providing for affirmative relief since Brown. ${ }^{37}$ In Milliken, a sharply divided Court prohibited the imposition of areawide remedies to counteract the impact of racially isolated schools, caused in part by white flight to suburban areas. This decision dramatically limited the use of practical remedies such as busing across district lines to correct racially imbalanced schools. Milliken, then, effectively undercut the Court's previous support of affirmative systemwide

28. 132 F. Supp. 776 (E.D.S.C. 1955).

29. Id. Briggs was not expressly overruled until 1969 in Walker v. County School Bd., 413 F.2d S3, 54 n.2 (4th Cir. 1969), cert. denied, 396 U.S. 1061 (1970).

30. See Alexander v. Holmes County Bd. of Educ., 396 U.S. 19, 20 (1969).

31. 391 U.S. 430,442 (1968).

32. 391 U.S. 443 (1968).

33. McDaniel v. Barresi, 402 U.S. 39, 41 (1971).

34. Keyes v. School Dist. No. 1, Denver, Colo., 413 U.S. 189 (1973).

35. 402 U.S. 1, 15 (1971) (declaring power of federal courts to fashion equitable remedies is "broad").

36. 418 U.S. 717 (1974).

37. DERRICK A. BELL, JR., RACE, RACISM AND AMERICAN LAW $397-99$ (1980). See, e.g., Keyes, 413 U.S. 189; Swann, 402 U.S. 1; Alexander v. Holmes County Bd. of Educ., 396 U.S. 19 (1969); Green v. County School Bd., 391 U.S. 430 (1968). 
relief as provided in cases like Swann and Keyes. Milliken prevented busing across city and county lines even if the resulting school systems were predominantly Black and predominantly white.

Furthermore, the Court's recent decision in Board of Education v. Dowe $^{38}$ reflects a continued unwillingness to address the actual impact of school board policies on the racial composition of public schools. What began in Oklahoma as an effort to integrate a school system that had resisted meaningful integration for decades has been quashed by a return to segregation resulting from demographic trends whose effects this Court may be unwilling to address. ${ }^{39}$

The pending case of Pitts $v$. Freeman ${ }^{40}$ will test the Supreme Court's resolve in addressing a public school system's duty under Brown to overcome the effects of resegregation caused by white flight. If the Court's eventual ruling in Pitts follows Dowell's reasoning that courts need not continue to address the vestiges of segregation, it will be difficult for courts to characterize culturally sensitive curricula as unreasonable under the very circumstances the Supreme Court has allowed to continue. To the extent that the Supreme Court continues to hold that courts are powerless to redress racial inequities and disparities created by demographic factors, schools should be free to adopt programs that are culturally sensitive to the resulting student bodies, so long as such programs are not racially exclusive.

\section{THe NeEd FOR AN AFROCENTRIC CURRICULUM}

\section{A. The Current Crisis in the Education of Black Children}

While many Blacks took advantage of the wider opportunities afforded by the civil rights movement to join mainstream society, poor Blacks found themselves isolated when middle class Blacks moved out of the inner city, creating urban ghettos. The urban riots of the late 1960's further destabilized these communities, as did problems such as increasing infant mortality, drug abuse, Black-on-Black crime, high incarceration rates, and reduction in the number of Black two-parent families. ${ }^{41}$ In addition, many school systems encountered new problems, such as dramatic increases in teenage pregnancy and high dropout rates. ${ }^{42}$

38. 111 S. Ct. 630 (1991).

39. Cf. id. at 639, 645-46 (Marshall, J., dissenting) (noting that majority failed to recognize threatened reemergence of one-race schools as relevant vestige of de jure segregation).

40. 887 F.2d 1438 (11th Cir. 1989), cert. granted, 111 S. Ct. 949 (1991).

41. See NATIONAL ADVISORY COMM'N ON CIVIL DISORDERS, REPORT OF THE NATIONAL ADVISORY COMM'N ON CIVIL DISORDERS (1968) (report by Kerner Commission).

42. See COMMITTEE ON POLICY FOR RACIAL JUSTICE, supra note 2, at 15 (outlining educational barriers accompanying host of problems confronting Black lower classes). 
Many Blacks who joined the middle class and who integrated white neighborhoods found themselves subject to intense racial hostility, and they worried about the racial isolation of their children. Even though their children attended predominantly white schools, a disproportionate number of them were "tracked" into remedial programs and special education classes, which dramatically reduced their chances for attending college. ${ }^{43}$ Those Black children who gained access to higher achievement tracks often found themselves steered toward community colleges and vocational technical programs. ${ }^{44}$ Those who attended predominantly white colleges encountered backlash against affirmative action and increasingly hostile racial tensions on many campuses. ${ }^{45}$

Social conditions within the Black community appear to be worsening, and many communities are struggling to find ways to reverse these negative trends. ${ }^{46}$ At the same time, race-based remedies to discriminatory practices in education, housing, and employment have been subject to increasing attack by the general public and declining support from the Supreme Court and executive branch. Some commentators have suggested that whites in America have turned their backs on the problems of Black America ${ }^{47}$ and that "the good life" for many does not now include any social contact with Blacks. Such abandonment is particularly evident in public education and is one of the main reasons schools are now more likely to have either a majority of white students or a majority of minority students.

As long as inadequately funded inner-city Black schools continue using traditional Eurocentric models for instruction, the general public will remain unconcerned about the quality of education in those schools, namely whether those students are effectively taught or merely warehoused. But if an inner-city school instead proposes an Afrocentric model, based on Black cultural experiences and values, that school can expect a legal challenge to the implementation of such a program. ${ }^{48}$

\section{B. The Afrocentric Curriculum as a Response}

These developments have fostered a renewed inquiry into the legitimacy of the integrationist model of the civil rights movement as the only way to

43. Id. at 17-19 (Black children are disproportionately placed in lower ability groupings and noncollege-bound tracks); $c f$. JEANNIE OAKES, KEEPING TRACK: HOW SCHOOLS STRUCTURE INEQUALTYY (1985) (discussing tracking of Mexican-American high school students).

44. COMMITTEE ON POLICY FOR RACIAL JUSTICE, supra note 2, at 17.

45. Bem P. Allen \& James F. Niss, A Chill in the College Classroom?, PHI DELTA KAPPAN, Apr. 1990, at 607-09 (discussing study demonstrating professors' negative classroom reactions to comments of minority students, especially those of black female students).

46. See Floretta D. McKenzie, Education Strategies for the 90's, in THE STATE OF BLACK AMERICA 95, 108 (Janet Dewart ed., 1991).

47. Cf. Thomas B. Edsall \& Mary D. Edsall, Race, ATLANTIC MONTHLX, May 1991, at 53-55 (arguing that race influences contemporary domestic politics).

48. Ironically, such attention could have a positive effect, by focusing attention on the problems of inner-city schools. 
achieve equal educational opportunity. ${ }^{49}$ Many college-bound students are attending predominantly Black institutions where they experience a more supportive environment. Black students who attend predominantly white public schools are insisting on more culturally sensitive curricula, as evidenced by the debate over multicultural programs in higher education. ${ }^{50}$

For children attending predominantly Black schools, the curricular debate is particularly heated. One issue is whether teaching basic public school courses from an Afrocentric perspective would improve the self-confidence and esteem of African-American schoolchildren who are likely to experience severe social problems. A second issue is whether an Afrocentric approach should be adopted as a means of asserting community control over a predominantly Black school.

Large inner-city school systems usually have predominantly minority student bodies as a result of past de jure segregation, failed desegregation efforts in de facto settings, persistent residential segregation, demographic forces, or a combination of these factors. ${ }^{51}$ It is undisputed among educators that Black children attending schools that do not receive the same resources and funding as white suburban schools are at a serious disadvantage. The problem of equalization of resources between inner-city schools and suburban schools, or even between rural schools and suburban schools, has not been resolved by the courts in a manner that produces equality in the actual distribution of governmental resources. ${ }^{52}$

The issue of curricular development is gaining attention in academic circles as educators grapple with the problems of administering public school systems whose minority student concentrations over the past two decades have increased dramatically. ${ }^{53}$ While the adoption of multicultural curricula has been controversial, it has not generated the intense emotional response or negative reaction that Afrocentric curricular proposals have received to date. ${ }^{54}$ Indeed, within Black academic circles, lines are being drawn between those who favor an Afrocentric approach to education, those who favor a broader multicultural approach, and those who favor a more traditional approach. ${ }^{55}$

49. SHADES OF BROWN: NEW PERSPECTIVES ON SCHOOL DESEGREGATION, supra note 2, at 52.

50. For example, minority students at Stanford University who challenged the lack of minority and female authors in the Western Civilization course were criticized on national television by former Secretary of Education William Bennett.

51. Cf. National Comm'N on Excellence in Education, A Nation At Risk 24-27 (1983).

52. See, e.g., Kadrmas v. Dickinson Pub. Sch., 487 U.S. 450 (1988) (user fees for bus transportation permissible under 14th Amendment even if family's inability to pay prohibited child from attending school); San Antonio Indep. Sch. Dist. v. Rodriguez, 411 U.S. 1 (1973) (mere showing of unequal spending between districts does not violate Equal Protection Clause).

53. See Karen DeWitt, Large Increase Is Predicted in Minorities in U.S. Schools, N.Y. TMES, Sept. 13, 1991, at A14 (reporting dramatic surge in school-age minority populations and its effect on overall dropout rates).

54. Charles A. Tesconi, Jr, Multiculturalism in Education: The Importance of Meaning, in ADULT EDUCATION IN A MULTICULTURAL SOCIETY 37-38 (Beverly Cassara ed., 1990).

55. Cf. Asa G. Hilliard, III, Straight Talk About School Desegregation Problems, 17 THEORY INTO PRACTICE 100-03 (1978) (claiming multicultural perspectives are product of teaching "truth" rather than just Eurocentrism); IRVINE, supra note 8, at 88-93 (1990) (reviewing literature on effects of Afrocentric 
An Afrocentric curriculum teaches basic courses from a perspective that uses Africa and the societal contributions of African Americans as its reference points. It seeks to counteract a Eurocentric model of instruction, one based solely on the perspective of white males. Advocates of the theory underlying the Afrocentric curriculum claim that an Afrocentric perspective would empower Black schoolchildren by improving their self-confidence, their self-esteem, and, consequently, their educational achievement. ${ }^{56}$ This theory further assumes that heightened self-esteem and self-confidence are critical for combating problems such as teenage pregnancy, high dropout rates, and antisocial behavior. A related expectation is that correction of racial bias and historical distortions would produce greater understanding between the races. The model discussed in this Essay is not merely an expanded Black history course, but rather an infusion of Afrocentric content into a curriculum. ${ }^{57}$

An Afrocentric curriculum provides students with an opportunity to study concepts, history, and the world from an Africa-centered perspective. ${ }^{58}$ Instead of centering education solely on the perspectives and experiences of white Europeans, who rely on Ancient Greece as the focal point of civilization, Afrocentric scholars posit Ancient Kemetic or Egyptian civilization as the point of reference for the study of civilization.

Advocates for the adoption of an Afrocentric approach argue that because integration has not resulted in equal educational opportunity for Black children, educators should focus more attention on culturally sensitive ways to improve schools whose students are virtually all Black. ${ }^{59}$ Others further assert that under some circumstances, separate schools may actually provide a better educational experience than many Black students have faced in integrated settings. In support of this view, they point to the dramatic increase in attendance and graduation rates at historically Black colleges over the past ten years. ${ }^{60}$ Proponents also argue that an Afrocentric approach would strengthen

curriculum).

56. Gary Putka, Curricula of Color: Course Work Stressing Blacks' Role Has Critics But Appears Effective, WALL ST. J., July 1, 1991, at A1-A2 (Atlanta schcols that incorporated Afrocentric curriculum have seen increased standardized test scores, attendance rates, reading norms, and self-esteem); see also Asante, supra note 9, at 177.

57. See, e.g., Barbara Kantrowitz, $A$ is for Ashanti, $B$ is for Black . . . And C is for curriculum which is starting to change, NEwswEEK, Sept. 23, 1991, at 45-48; Andrew L. Yarrow, Afrocentric Brooklyn School Opens, N.Y. TMES, Oct. 6, 1991, at 34.

58. See MOLEFI K. ASANTE, THE AFROCENTRIC IDEA (1987); Asante, supra note 9, at 171; see also Infusion of African and African American Content in the School Curriculum, in PROCEEDINGS OF THE FIRST NATIONAL CONFERENCE OCTOBER 1989 (Asa G. Hilliard, III et al. eds, 1990). 93.

59. See William Brazziel, Quality Integrated Education, 17 THEORY INTO PRACTICE, Apr. 1978, at

60. See Gil Kujovich, Equal Opportunity in Higher Education and the Black Public College: The Era of Separate But Equal, 72 MINN. L. REv. 29, 38-39 (1987); Black Colleges: Degrees in Poverty, EcoNoMIST, Mar. 21, 1987, at 33-34 ("Most of today's prominent blacks are products of the traditionally black colleges.") 
community control over Black public schools-schools largely abandoned by the white community. ${ }^{61}$

Opponents of Afrocentrism argue that substituting such an approach is both self-defeating and limiting because it reinforces the stigma that Brown sought to correct. ${ }^{62}$ Traditionalists argue that Black students taught in such schools would be further handicapped with respect to performance on standardized tests and would not learn how to compete in this country's pluralistic society. Such critics further stress the importance for Black youngsters to excel in basic courses (such as math, science, and English) that will better prepare them for the more technological and service-oriented job market that awaits them. ${ }^{63}$ Finally, opponents charge that an Afrocentric program is basically separatist in nature and abandons the important societal goal, implicit in Brown, that both Black and white students benefit from exposure to other races.

Moreover, multicultural proponents argue that an Afrocentric perspective, much like the Eurocentric approach, is too narrow and fails to value properly the contributions of other minority cultures. Without a holistic, multicultural approach to education, the Afrocentric curriculum runs the same risk of distortion and cultural bias existing in the Eurocentric curriculum. ${ }^{64}$ The multiculturalists contend that a better alternative is to restructure classroom instruction to reflect the full diversity of American society. ${ }^{65}$

The existence of only limited experience with an Afrocentric curriculum suggests that such a program should be viewed as a recently begun experiment. Wider application is sure to ignite an emotional response. Hence, this Essay assesses the legality of the Afrocentric curriculum to anticipate potential challenges to this experiment.

\section{A CONSTItUtional ANALysis of the AFrocentric CURRICULUM}

Under Brown and its progeny, school authorities bear the burden of showing that the existence of racially homogeneous schools is not the result of discrimination. ${ }^{66}$ Those authorities may consider race when fashioning techniques designed to promote desegregation. ${ }^{67}$ When no feasible desegregation techniques exist, the authorities may order specific remedial programs for the

\footnotetext{
61. Nelson, supra note 11 , at 127.

62. McKenzie, supra note 46, at 99-100; Diane Ravitch, Diversity and Democracy, AM. EDUCATOR, Spring 1990, at 20.

63. See, e.g., COMMITTEE ON POLICY FOR RACLAL JUSTICE, supra note 2; EDUCATING BLACK CHILDREN: AMIERICA'S CHALLENGE (Dorothy S. Strickland \& Eric J. Cooper eds., 1987).

64. McKenzie, supra note 46 , at 100 . Columnist William Raspberry argues that emphasis on cultural diversity should not become a campaign to prove Black superiority. William Raspberry, Ethnocentric Excesses, Wash. Post, Oct. 5, 1991, at A19.

65. McKenzie, supra note 46 , at 100 .

66. Swann v. Charlotte-Mecklenburg Bd. of Educ., 402 U.S. 1, 15 (1971).

67. Green v. County Sch. Bd., 391 U.S. 430, 437-38 (1968) (school officials have "affirmative duty to take whatever steps might be necessary to convert to a unitary system in which racial discrimination would be eliminated root and branch").
} 
students remaining in racially homogeneous schools as a means of ensuring equal educational opportunity. ${ }^{68}$ In Milliken v. Bradley (Milliken II) ${ }^{69}$ for example, the Supreme Court approved a school board's desegregation plan that included alternative educational components such as multiethnic curricula, curriculum design, and bilingual education as part of a compensatory program. ${ }^{70}$

Thus, the primary issue is whether the adoption of Afrocentric curricula in racially homogeneous schools may be viewed as an appropriate remedial device to ensure equal educational opportunity for Black students. Critics of the Afrocentric approach posit two major objections. First, claims that such curricula have the capacity to improve both the self-esteem and educational achievement of Black students have not been supported by empirical studies. Second, the Afrocentric program is separatist by design and ensures one-race schools, its real purpose being political, not pedagogical.

The first objection appears more serious under Brown's Fourteenth Amendment analysis. If Black children taught through an Afrocentric program actually perform worse according to objective measurements of educational achievement, then one could argue that those children were denied access to an equal educational opportunity as required in Brown. The converse, however, is also true: if it can be demonstrated that the Afrocentric curriculum does in fact lead to greater self-esteem and educational achievement, Brown is satisfied because Brown's central concern was the ultimate welfare of the children. ${ }^{71}$ Moreover, if the Afrocentric approach can meet the special needs of its student population, then the analysis shifts to whether the approach is consistent with constitutional principles established in other areas that have programs geared towards special populations, such as bilingual education and disability programs. ${ }^{72}$

The second objection, that the Afrocentric approach is separatist, implicates the Brown holding that separate schooling is inherently unequal. To the extent that Afrocentric curricula are currently adopted in already all-Black settings, such adoption would not cause racially identifiable schools or resegregation in

68. See, e.g., Liddell v. Missouri, 731 F.2d 1294, 1313 (8th Cir.), cert. denied, 469 U.S. 816 (1984) (affirming lower court's use of remedial programs to provide equal educational opportunity for Black students remaining in one-race schools following desegregation plan).

69. 433 U.S. 267, 272 (1977) (Milliken II).

70. The trial court found that all aspects of the educational offerings were discriminatory, including testing, counseling, and discipline. Bradley v. Milliken, 402 F. Supp. 1096, 1118 (E.D. Mich. 1975), aff $d$, 540 F.2d 229 (6th Cir. 1976), aff'd, 433 U.S. 267 (1977).

71. In Brown, the Supreme Court highlighted the importance of education to a successful future, declaring education the "principal instrument in awakening [a] child to cultural values, in preparing him for later professional training, and in helping him to adjust normally to his environment." Brown v. Board of Educ., 347 U.S. 483, 493 (1954). The city of Atlanta has adopted an Afrocentric curriculum for a school system that is $92 \%$ Black, with Blacks comprising $93 \%$ of all staff. The early results indicate a noticeable increase in self-esteem and academic achievement levels for the schools adopting the Afrocentric approach. See Putka, supra note 56.

72. See, e.g., Lau v. Nichols, 414 U.S. 563 (1974); Bonnie P. Tucker, Section 504 of The Rehabilitation Act After Ten Years of Enforcement: The Past and The Future, 1989 U. ILL. L. REV. 845, 849. 
violation of $B$ rown. ${ }^{73}$ However, if a school is only primarily Black but not allBlack, the adoption of such curricula could cause non-Blacks to withdraw from the school system in even greater numbers, which would conflict with Brown. As noted above, school boards bear the burden of showing that one-race schools are not the result of present discrimination. The courts have encouraged school boards to adopt techniques to encourage whites to remain in the school system, such as magnet schools and the termination of busing programs. ${ }^{74}$

However, the heightened controversy over the Afrocentric curricula arises not from a concern for white students or other non-Black students who might choose to withdraw from a school adopting such an approach. Rather, the heat is generated by the political nature of the movement-the dispute concerns a way to control the educational content of what children learn. ${ }^{75}$ In this instance, the First Amendment, rather than the Equal Protection Clause, would be the starting point of any legal analysis.

Since controversies over curricular content are hardly novel, the controversy over Afrocentric content should be viewed as yet another chapter in the history of disputes over values. ${ }^{76} \mathrm{~A}$ state might object to an individual school board's decision to adopt such curricula on the grounds that Afrocentric curricula are incompatible with state-approved curricula. ${ }^{77}$

The courts have given great weight to a state's discretion to define the course of instruction in its public schools. ${ }^{78}$ However, the Supreme Court has held that the exercise of unfettered discretion may run afoul of the First

73. In Pitts v. Freeman, 887 F.2d 1438 (11th Cir. 1989), cert. granted, 111 S. Ct. 949 (1991), the court held that the formerly de jure dual school system had not achieved unitary status because of the presence of racially identifiable schools. However, the court did not reach the question of whether a school system may constitutionally operate a system that is in fact segregated after the system has achieved unitary status or whether the spirit of Brown would provide a cause of action for a new set of plaintiffs. Id. at 1450 n.15.

74. Some have criticized magnet schools for siphoning off the brightest students (Black as well as white), thereby adversely affecting the educational offerings at schools without enhanced programs. Magnet schools, however, have generally passed constitutional muster as long as they were not a smokescreen for resegregation. See Janet R. Price \& Janet Stern, Magnet Schools as a Strategy for Integration and School Reform, 5 YALE L. \& POL'Y REV. 291, 296-97 (1987).

75. Bilingual education has also been criticized for being mainly political and not pedagogical. See Peter Margulies, Bilingual Education, Remedial Language Instruction, Title VI, and Proof of Discriminatory Purpose: A Suggested Approach, 17 ColuM. J.L. \& SoC. PRoBS. 99, 106 (1981).

76. Geneva Gay, Achieving Educational Equality Through Curriculum Desegregation, PHI DELTA KAPPAN, Sept. 1990, at 56; see also FRANCIS FITZGERALD, AMERICA REVISED: HISTORY SCHOOLBOOKS IN THE TWENTIETH CENTURY (1979).

77. A state might argue that Afrocentric curricula fail to prepare students to pass state-approved tests because they do not expose students to the materials upon which those tests are based. Moreover, if the state-approved curricula seek to inculcate societal (i.e., Eurocentric) values, then Afrocentric curricula that contain markedly different values might be inconsistent with mainstream values and lacking in pedagogical content since the scholarship basis has not yet been established. See, e.g., ARTHUR M. SCHLESINGER, JR., THE DISUNITING OF AMERICA (1991).

78. See, e.g., Board of Educ., Island Trees Union Free Sch. Dist. No. 26 v. Pico, 457 U.S. 853 (1982); Ambach v. Norwick, 441 U.S. 68 (1979); Presidents Council, Dist. 25 v. Community Sch. Bd. No. 25,457 F.2d 289 (2d Cir.), cert. denied, 409 U.S. 998 (1972); see also Lee Prey, Note, What Are the Limits to a School Board's Authority to Remove Books From School Library Shelves?, 1982 WIS. L. REV. 417. 
Amendment. ${ }^{79}$ As the plurality noted in Board of Education v. Pico, ${ }^{80}$ involving the removal of controversial books from a school's library:

We have ... acknowledged that public schools are vitally important "in the preparation of individuals for participation as citizens," ... [L]ocal school boards must be permitted "to establish and apply their curriculum in such a way as to transmit community values,"... .

At the same time, however, we have necessarily recognized that the discretion of the States and local school boards in matters of education must be exercised in a manner that comports with the transcendent imperatives of the First Amendment. ${ }^{81}$

The Court has not further developed a student's "right of access" to controversial materials in a secondary school setting. ${ }^{82}$ Yet it is clear that if a school board were to reject an Afrocentric curriculum because the state disapproved of views written by Black authors, both the students' freedom of belief and the teachers' right to academic freedom would be implicated. ${ }^{83} \mathrm{~A}$ state's policies regarding the use of an approved curriculum raise First Amendment issues because those policies affect a teacher's ability to teach, a student's opportunity to be exposed to a diversity of viewpoints, and the overall quality of the educational experience. ${ }^{84}$

A school board's adoption of an Afrocentric curriculum, recognizing the importance of African-American values and culture to its children, could also be viewed as part of an ideological movement to transform the traditional curriculum. ${ }^{85}$ In effect, the school board would be rejecting the ideological orthodoxy of the Eurocentric model in favor of one more responsive to its community ${ }^{86}$ An Afrocentric curriculum adopted in an all-Black school would challenge an orthodox framework by stressing racial pride and individual empowerment.

79. Pico, 457 U.S. at 864 (citing West Virginia State Bd. of Educ. v. Barnette, 319 U.S. 624 (1943)); cf. Epperson v. Arkansas, 393 U.S. 97, 104 (1968); Meyer v. Nebraska, 262 U.S. 390 (1923).

80. 457 U.S. $853,864$.

81. Id. (citations omitted). But cf. id. at 914 (Rehnquist, J., dissenting) (stating that allowing students "right of access in the school to information other than that thought by their educators to be necessary is contrary to the very nature of an inculcative education"). Even the dissenting Justices agreed that a school board cannot ignore the impact of the First Amendment in the operation of its public schools. Id. at 886 (Burger, C.J., dissenting); see also Howard O. Hunter, Curriculum, Pedagogy and the Constitutional Rights of Teachers in Secondary Schools, 25 WM. \& MARY L. REV. 1, 47 (1983).

82. See J. Peter Byrne, Academic Freedom: A "Special Concern of the First Amendment," 99 YALE L.J. 251, 262-63 (1989).

83. See generally Tyll van Geel, The Search for Constitutional Limits on Governmental Authority to Inculcate Youth, 62 TEX. L. REV. 197, 208-10 \& n.41 (1983).

84. Hunter, supra note 81 , at 75-76.

85. Gay, supra note 76 , at 61 .

86. See Pratt v. Independent Sch. Dist., No. 831, Forest Lake, Minn., 670 F.2d 771, 775-76 (8th Cir. 1982) (First Amendment claim recognized if book is excluded to suppress ideological viewpoint with which authorities disagree); Right to Read Defense Comm. v. School Comm., 454 F. Supp. 703, 710 \& n.12 (D. Mass. 1978); see also West Virginia State Bd. of Educ. v. Barnette, 319 U.S. 624, 637 (1943). 
Implicit in Afrocentric curricula is a rejection of the integrationist approach to education promoted ever since Brown; instead of being stigmatized by separateness, children would be taught to celebrate their opportunity to learn from a perspective more responsive to their cultural needs. ${ }^{87} \mathrm{~A}$ school board favoring an Afrocentric curriculum could argue that a required Eurocentric curriculum that excluded any other perspective constitutes a form of coerced ideological indoctrination contrary to the fundamental tenets of the First Amendment. ${ }^{88}$ Students denied access to Afrocentric materials could claim that their rights to receive information and to be exposed to controversial ideas are fundamental First Amendment rights. ${ }^{89}$ Once a school board is able to demonstrate that the state's rejection of an Afrocentric curriculum is subject to constitutional restraints, schoolteachers may also assert their First Amendment rights to protect their academic freedom to teach such courses. ${ }^{90}$

Present case law does not articulate the extent to which a state's interest in inculcating a prescribed set of Eurocentric values in schoolchildren may override one that promotes Afrocentric values. ${ }^{91}$ Notwithstanding a state's recognized right to control curricular content, it seems clear that students, teachers, and school boards would have standing to assert a First Amendment challenge if a state rejected an Afrocentric curriculum for purely political reasons or for protecting a rigid and doctrinaire curriculum.

Since most states are legally responsible for approving curricula and textbooks used by individual public schools, widespread adoption of Afrocentric curricula outside of inner-city schools is unlikely. If an individual school board

87. Asante, supra note 9 , at 177.

88. Cf. Keyishian v. Board of Regents, 385 U.S. 589, 603 (1967) (First Amendment does not allow "pall of orthodoxy" to be cast over classroom); Barnette, 319 U.S. at 642 . Commentators who criticize the value of Afrocentric curricula still acknowledge that traditional (or Eurocentric) curricula have been exclusionary or racist in the past and serve to maintain the status quo. Compare Asante, supra note 9 with Alvin F. Poussaint, It Ain't No Consolation, in EdUCATING BLACK CHILDREN 50 (Dorothy S. Strickland \& Eric J. Casper eds., 1987) ("What we should acknowledge is an educational system shaped for white middle and upper-class kids ... .") and Robert Reinhold, Class Struggle: California's Texibook Debate, N.Y. TMES, Sept. 29, 1991, § 6 (Magazine), at 46 (citing criticisms that textbooks to reflect cultural diversity "remain essentially, if unintentionally, racist") and CAROLINE CODY, THE POLITICS OF TEXTBOOK PUBlishng, ADOPTION, AND USE, TEXTBOOKS AND SCHOOLING IN THE UNITED STATES 138-39 (David Elliott \& Arthur Woodward eds., 1990) ("Values issues have been contentious throughout our country's history, but until minority groups grew strong enough to exert their own political pressure, to elect board members of their persuasion, and until, in some cases, they gained the support of the courts for their point, boards that commonly held the traditional white Protestant, middle-class point of view held firm.").

89. Right to Read, 454 F. Supp. at 714 ("What is at stake here is the right to read and be exposed to controversial thoughts and language-a valuable right subject to First Amendment protection."); see also Elrod v. Burns, 427 U.S. 347, 356-57 (1976); Pratt, 670 F.2d at 775-76 (citing Epperson v. Arkansas, 393 U.S. 97 (1968), and Pico v. Board of Educ., Island Trees Union Free Sch. Dist., 638 F.2d 404 (2d Cir. 1960)).

90. Loewen v. Turnipseed, 488 F. Supp. 1138, I151 (N.D. Miss. 1980); van Geel, supra note 83.

91. Compare Hunter, supra note 81, at 64 \& n.284 with Rust v. Sullivan, 111 S. Ct. 1759 (1991) (recent case involving abortion counseling suggesting that federal government may suppress expression of ideas it has decided not to fund without violating First Amendment) and Lewis H. Lapham, Tyromancy, HARPER'S, Aug. 1991, at 6-8 (under Rust, a school could "be made to inform the curriculum with whatever truths the government finds most flattering to its own image of itself'). 
were to pay for Afrocentric textbooks and materials out of its own budget, however, that school board could survive a conflict with the state over content. The school board might then face a legal challenge from a dissatisfied parent. ${ }^{92}$

Challenges to Afrocentric curricula are more likely to come from Black parents than white parents for several reasons. More middle class Black parents send their children to public schools than their white counterparts. Black parents, regardless of class, are concerned that their children do not have access to the same education as white children and thus are prevented from having an equal chance to be competitive and productive members of society. To the extent an Afrocentric curriculum would not adequately prepare Black children to take state-approved tests or standardized national tests, Black parents might argue that such a program in a resegregated setting only further stigmatizes graduates of the program. ${ }^{93}$

As Justice Marshall noted in his final dissent in Dowell, remedying and avoiding the recurrence of the stigmatizing harm of racially identifiable schools was the guiding objective of the Supreme Court's desegregation jurisprudence for nearly three decades. ${ }^{94}$ Consequently, arguments concerning stigma carry considerable weight. But the real issue here is whether the stigma results from the persistence of racially identifiable schools or from adopting an alternative Afrocentric curriculum.

Black parents might assert that a nontraditional curriculum deprives their children of the equal educational opportunity required by Brown by not covering the same subjects non-Black children study. In other words, the Afrocentric curriculum could intensify the stigma Black children face by failing to prepare them for standardized state and national tests, tests based on Eurocentric curricula. They could claim that Black children are injured by attending racially identifiable schools that use race-specific curricula, resulting in racial isolation. ${ }^{95}$

Unequal learning opportunities persist, and students will not perform well on tests if they have not received basic instruction in the materials underlying such tests. ${ }^{96}$ If Black parents could show that Afrocentric textbooks and mate-

92. For example, a local school board in Oakland, dissatisfied with California's new multicultural textbooks, elected to develop its own materials. But the delay in creating new materials more sensitive to Blacks has created more problems than it has solved. See Jane Gross, A City's Determination to Rewrite History Puts Its Classrooms in Chaos, N.Y. TMMES, Sept. 18, 1991, at A17.

93. Parents are well aware of the impact of test scores on college admissions.

94. Board of Educ. v. Dowell, 111 S. Ct. 630, 642 (1991) (Marshall, J., dissenting).

95. In Reed v. Rhodes, 455 F. Supp. 569, 597-602 (N.D. Ohio 1978), the court found that a school that maintained a de jure system had a constitutional obligation to develop educational programs that would maintain a secure, integrated school environment and prevent resegregation resulting from testing and tracking, curriculum choices, and extracurricular activities. In Allen v. Wright, 468 U.S. 737, 756 (1984), the Supreme Court recognized that a child's diminished ability to receive an education in a racially integrated school is not only legally cognizable but "one of the most serious injuries recognized in our legal system."

96. See Gay, supra note 76 , at 61 . 
rials failed to prepare their children adequately for state-approved tests, this would be a prima facie equal protection claim under Brown. They might allege that their children had been denied equal access to the educational opportunities available to the children exposed to the traditional curriculum. ${ }^{97}$ Such parents would have the burden of proving that discriminatory intent by the school board caused the harm of lower test scores, and that the disparate impact was not the result of other factors, ${ }^{98}$ such as the lack of resources received by one-race schools. ${ }^{99}$

This claim, however, would falter if the school could demonstrate that its students' performances on standardized tests were the same or even better than before the adoption of the Afrocentric curriculum. Alternative curricula are not inherently suspect since schools are constantly seeking ways to improve the educational content of their course offerings. Proponents of Afrocentric curricula believe that a more relevant education will improve students' overall academic achievement. ${ }^{100}$ If this proves to be the case, students whose performance improved would find it difficult to argue that they have been deprived of an equal educational opportunity. ${ }^{101}$

Although desegregation's goal is to eliminate racially identifiable schools, certain remedial educational devices may also prevent the stigma placed on Black children from becoming self-perpetuating. ${ }^{102}$ Afrocentric curricula promote Brown's aim of removing the psychological ignominy Black schoolchildren experience in segregated settings. Schools have been using alternative curricula as remedial devices for years, and the courts have given school boards great latitude in designing courses of study. Thus, if an Afrocentric curriculum does improve Black students' academic performance by helping them to

97. See IRVINE, supra note 8, at 91 (noting need for empirical base to support some Afrocentric prescriptions). In addition, standardized tests have been criticized as culturally biased. One study found that Blacks in segregated schools had higher grades but scored lower on standardized tests than those in more heterogeneous settings. Janice Streitmatter, School Desegregation and Identity Development, 23 URB. EDUC. 280, 287 (1988).

98. See Riddick v. School Bd., 784 F.2d 521, 543 (4th Cir. 1986) (disparate impact alone does not violate Constitution).

99. See Board of Educ. v. Dowell, 111 S. Ct. 630, 643 (1991) (Marshall, J., dissenting) (AfricanAmerican public schools typically receive fewer resources than other schools in same district).

100. Asante, supra note 9, at 179. Any program that has the potential to improve performance should be encouraged. The Court in Martin Luther King Jr. Elementary Sch. Children v. Ann Arbor Sch. Dist. Bd., 473 F. Supp. 1371, 1382 (E.D. Mich. 1979), stated that while "courts are not the place to test the validity of educational programs," courts can assess whether children have benefitted from the adoption of such programs.

101. The recent case of Ayers v. Allain, 914 F.2d 676 (5th Cir. 1990) (en banc), cert. granted sub nom. Ayers v. Mabus, 111 S. Ct. 1579 (1991), demonstrates the dangers of overreliance on standardized test scores. Colleges in Mississippi typically use minimum scores on the ACT, a standardized test, to determine eligibility for admission. This practice was approved by the court despite the disparate impact it had on Black students and despite the fact that the ACT requirement was initially adopted as a way to impede the admission of Black students. Id. at 679,690-91. This case is currently before the Supreme Court.

102. Dowell, 111 S. Ct. at 642-43 (Marshall, J., dissenting). 
overcome this stigma, establishing the sufficient harm to make such a program constitutionally invalid seems unlikely. ${ }^{103}$

A more difficult challenge would arise if an Afrocentric curriculum were initiated in a school that was predominantly, but not exclusively, Black (for example $70 \%$ Black, $15 \%$ Hispanic, and $15 \%$ white). The non-Black students might argue that a racially centered curriculum constitutes "reverse discrimination" against them by promoting the needs of Black students to the detriment of others. ${ }^{104}$ In addition, these students might assert that the Afrocentric curriculum actually fosters segregation through the explicit use of a certain racial perspective making them, as non-Blacks, feel excluded.

The argument that the Afrocentric model will improve the self-esteem of Black children, even if conclusively demonstrated, does not have the same force with respect to non-Black students. This undoubtedly accounts for the fact that multicultural, rather than Afrocentric, curricula are promoted in multiracial settings. ${ }^{105}$ However, Afrocentric advocates could counter that Afrocentricity is not simply the Black counterpart of Eurocentricity. Non-Black students can benefit from receiving Afrocentric instruction ${ }^{106}$ because it neither assumes European superiority nor denigrates non-Black students' experiences.

Nontraditional curricula emphasizing cultural pluralism have been approved as remedial devices even in integrated settings. ${ }^{107}$ To the extent that a school board can demonstrate that its Afrocentric curriculum does not promote racial

103. It will require some time before it will be possible to assess whether test scores improve under Afrocentric curricula. Preliminary data from Atlanta suggest that students find the new curricula engaging, which could in turn lead to better test scores. Such a pattern would make a characterization of such curricula as harmful incorrect, under either a strict scrutiny or heightened scrutiny approach. See Putka, supra note 56, at A1-A2 (noting preliminary data from Atlanta).

104. This argument gains some force if it appears that the test scores, attendance levels, and grades of the non-Black students suffer after the adoption of the curriculum. But again, these students would bear the burden of establishing both discriminatory intent and that other factors did not.cause the decline in scores.

105. See William C. Miller, Fostering a Commitment to Cultural Pluralism, 34 EDUC. LEADERSHIP 221 (1976). It is interesting to note that the Portland Baseline Studies, which have become the main reference point for the development of Afrocentric coursework, were developed in a system that is $74 \%$ white.

106. Asante, supra note 9 , at 174. Other fields have experienced a growing recognition that Africa had a profound impact on the development of homo sapiens and on civilization itself. See, e.g., 1 MARTIN BERNAL, BLACK ATHENA: THE AFROASIATIC ROOTS OF ClassiCAL CIVILIZATION (1987); Luigi CavalliSforza, Genes, Peoples and Language, ScI. AM., Nov. 1991, at 104, 106 (studies show "an African origin of our species").

107. In Lau v. Nichols, 414 U.S. 563, 568 (1974), the Court held that Title VI barred the discriminatory treatment of non-English speaking, Chinese students in order to provide those students with a meaningful education. In Martin Luther King Jr. Elementary Sch. Children v. Ann Arbor Sch. Dist. Bd., 473 F. Supp. $1371,1380-81$ (E.D. Mich. 1979), the court found that the inability of a small number of Black children in a predominantly white school system to develop reading skills in standard English impeded their equal participation in the instructional program under the Equal Educational Opportunities Act of 1974. Finally, in Reed v. Rhodes, 455 F. Supp. 569, 598 (N.D. Ohio 1978), the court reviewed virtually all aspects of the educational process before ordering compensatory relief under the 14th Amendment that would redress past segregation practices, maintain a secure integrated environment, and not cause resegregation. 
bias, such a curriculum should be able to withstand constitutional scrutiny. ${ }^{108}$ In order to survive a challenge under Washington v. Davis ${ }^{109}$ and Regents of California v. Bakke, ${ }^{110}$ the school board would have to meet the burden of showing that its curriculum was not intended to exclude members of other races.

Moreover, materials that are historically accurate and specifically tailored to correct past cultural biases are a valid form of scholarship. That they are based on the work of Black authors and educators does not render them constitutionally suspect even under Bakke. If the curriculum nonetheless encourages white flight from the school system, the school board would have a duty to take steps to retain white students in order to prevent the reemergence of racially identifiable schools as proscribed by Brown.

Programs designed to meet the special educational needs of bilingual or disabled students have passed constitutional muster because they do not deprive monolingual or able-bodied students of an equal education. Assuming that the pedagogical value of the Afrocentric curriculum could be shown, non-Black students would encounter difficulty in establishing that its adoption had interfered with their rights to equal educational opportunity as provided under Brown and Title VI of the Civil Rights Act. ${ }^{111}$

If the Afrocentric model leads to greater achievement by objective standards, then it is consistent with Brown's primary premise that Black children should not be educationally disadvantaged because of race. ${ }^{112}$ Following Brown's secondary emphasis on the importance of culture and self-esteem to Black children's psychological development, the Afrocentric model can be viewed as a means of instilling pride in Black children and providing them with the tools to compete effectively. An Afrocentric curriculum may also be used in an integrated setting as long as the program does not discriminate against non-Black students.

The Court's failure to remedy the continued vestiges of segregation makes it appropriate for school boards confronting the problem of resegregated schools to develop educational programs intended to remove the racial stigma that

108. See, e.g., Evans v. Buchanan, 582 F.2d 750, 771 (3d Cir. 1978) (order directing adoption of curriculum offerings which emphasized and reflected cultural pluralism of students); Reed v. Rhodes, 455 F. Supp. 569; Bradley v. Milliken, 402 F. Supp. 1096, 1118 (E.D. Mich. 1975); cf. Tracy E. Sivitz, Eliminating the Continuing Effects of the Violation: Compensatory Education as a Remedy for Unlawful School Segregation, 97 YALE L.J. 1173 (1988).

109. 426 U.S. 229 (1976).

110. 438 U.S. 265 (1978).

111. During the 1980 's, courts continued to recognize that a child's diminished ability to receive an education in a racially integrated school was a serious injury. The Department of Justice, however, was reluctant to force the Department of Education to rectify the situation as required under Title VI, 42 U.S.C. $\S \S 2000 d$ to $2000 d-4 a$ (1988). See Adams v. Bennett, 675 F. Supp. 668, 676 (D.D.C. 1987).

112. See Little Rock Sch. Dist. v. Pulaski County, 778 F.2d. 404, 408 (8th Cir. 1985); Tasby v. Black Coalition to Maximize Educ., 771 F.2d 849 (5th Cir. 1985); Martin Luther King Jr. Elementary, 473 F. Supp. 1371. 
Brown attempted to eradicate. Race continues to carry a stigma that requires new approaches to an age-old problem.

\section{CONCLUSION}

Afrocentric curricula can help to meet the needs of Blacks in public schools that remain polarized despite thirty-eight years of desegregation. Such curricula promote Brown's goal of improving the opportunities of Black schoolchildren. Such curricula need not be racially exclusive; they can provide educational benefits to non-Black students as well.

A curriculum which simply replaces Eurocentric orthodoxy with an Afrocentric one would not in and of itself improve educational opportunities for Black children. Therefore, it would face challenges from those who fear it would doom integration. However, the important goal of having non-racially identifiable schools need not be repudiated by a well-designed Afrocentric curriculum. If a school can increase academic achievement levels in a nonexclusionary fashion, it will attract rather than repel students, regardless of their race.

Brown's promise cannot be fulfilled if society continues to ignore the pervasiveness of racism. By itself, Brown cannot undo the legacy of centuries of segregation and neglect. The current debate over racial issues at all educational levels demonstrates how ingrained racism remains. Should the proponents of Afrocentric curricula succeed in establishing the connection between their programs and greater self-esteem and educational achievement, then such curricula would be entirely consistent with Brown's effort to improve the educational opportunities of African-American children. But if the movement stalls and becomes essentially a political issue, the Afrocentric program will become much more vulnerable to attack on constitutional grounds from Black and non-Black students alike. 